\title{
E-SPORT ARENA RESPON DARI KEBUTUHAN KAUM MILENIAL
}

\author{
Indro ${ }^{1)}$, Andi Surya Kurnia ${ }^{2)}$ \\ 1)Program Studi S1 Arsitektur, Fakultas Teknik, Universitas Tarumanagara, awiindro123@gmail.com \\ 2) Program Studi S1 Arsitektur, Fakultas Teknik, Universitas Tarumanagara, andik@ft.untar.ac.id
}

\begin{abstract}
Abstrak
E-Sport seperti di Korea Selatan menjadi salah satu pendapatan yang cukup besar bagi negara itu. E-Sport memiliki dampak yang cukup besar bagi sebuah negara. Karenanya E-Sport dipertandingkan dari lokal sampai ke internasional. Kebutuhan sarana untuk E-Sport juga sangat perlu apalagi dengan adanya tempat pelatihan bagi masyarakat yang ingin menjadi atlet E-Sport sehingga dapat mengikuti kompetisi di dunia Internasional. Di beberapa negara maju video game bukanlah lagi sebuah wahana untuk menghabiskan waktu luang melainkan menjadi sebuah profesi dengan pendapatan yang cukup meyakinkan. Profesi tersebut dengan adalah menjadi atlit professional dalam kasus ini yang ahli dalam bermain video game atau yang sudah banyak dikenal orang dengan sebutan e-Atlit. Di Indonesia sendiri, dengan diakuinya Indonesia E-Sport Association (IeSPA) sebagai organisasi yang diakui Kemenpora turut menjadi titik terang perkembangan olahraga ini di negeri kita. Untuk bangunan E-Sport di Indonesia sudah ada sejak dulu karenanya dalam perancangan akan memakai metode preseden untuk mengambil apa aja yang menjadi sebuah ciri bangunan E-Sport. Keberadaan bangunan E-Sport di Jakarta banyak terletak di Jakarta Barat terutama kawasan Palmerah, jadinya lokasi tapak diperkirakan berada di Palmerah.
\end{abstract}

Kata kunci: E-atlit; E-Sport; E-Sport arena

\begin{abstract}
E-Sport in South Korea has become one of the country's big income. E-Sport has a considerable influence on the country. Therefore E-Sport is questionable from local to international. The facilities needed for E-Sport also really need to be related to training places for people who want to become E-Sports athletes in order to be able to participate in international competitions. In some developed countries, the video game again recommends a vehicle to spend free time being asked to be a profession with income that is quite convincing. This profession is an Athlete professional in this case who is an expert in playing video games or who has been widely known as e-Athlete. If you have been given the title of the athlete, things that must be categorized in sports are given the name E-Sport. In Indonesia itself, with the recognition that the Indonesia E-Sport Association (IESPA) as an organization that respects Kemenpora is also a bright spot for the development of sports in our country. Although E-Sport shows don't seem difficult to do just because a computer with high specifications is needed, however, it is necessary to implement it requiring a place with a certain arrangement of spaces. So that athletes who will compete can simplify the game. Therefore a place that is specifically designed to carry out E-Sport events is needed.
\end{abstract}

Keywords: e-athlete; E-Sport; E-Sport arena

\section{PENDAHULUAN}

Olahraga elektronik / E-Sport juga dikenal sebagai permainan kompetitif, permainan pro, atau pro gaming di Korea Selatan merupakan suatu istilah untuk kompetisi Permainan video pemain jamak/ sendiri, umumnya antara para pemain profesional. Keberadaan E-Sport sudah ada sejak 1970 dalam bentuk konsol. E-Sport juga terus berkembang sampai dapat dimainkan di komputer. Dan sekarang berkembang ke gadget terutama handphone. Karena harga komputer sangat mahal, sekarang banyak yang lebih memilih E-Sport di handphone. Selain alasan harga, yang paling utama adalah dapat dibawa kemana-mana menjadikan handphone adalah kebutuhan yang penting bagi kaum milenial. 
Game MOBA dikalangan generasi milenial Indonesia cukup terkenal dikarenakan banyaknya kompetesi yang digelar dengan hadiah yang cukup fantastis, disamping itu Game MOBA menjadi banyak peminat dikarenakan para pro player biasanya mendapat eksitensi di dunia maya, misalnya di Youtube media berbagai dan menontong Video tersebut nama Evos. Jess No Limit dengan satu juta lebih followers bukanlah nama yang asing bagi generasi milenial dinegeri ini. Efek dengan banyaknya perlombaan yang digelar dalam game MOBA maka memunculkan lahirnya tim E-Sport dikalangan generasi Milenial , dengan banyaknya tim-tim ESport professional lahir maka ini menjadikan inspirasi bagi generasi generasi milenial untuk mencari "Geng" dengan cara menciptkan pula tim E-Sport bersama teman sepermainan (squad) dalam game tersebut. E-Sport semakin menjanjikan di Indonesia. Buktinya, beberapa tim E-Sport Indonesia sudah menoreh prestasi pada ajang kompetisi E-Sport di kalangan internasional.

Sarana-sarana E-Sport bahkan sudah ada sejak lama, contohnya seperti warnet-warnet. Akan tetapi karena berkembangnya teknologi menyebabkan E-Sport juga berkembang, bahkan sudah mencapai E-Sports VR (Virtual Reality). Dengan adanya VR ini akan ada kemungkinan dapat mengantikan keberadaan kegiatan Olahraga yang real. Contohnya olahraga tinju, sekarang sudah ada dalam VR. Keberadan teknologi VR ini juga dapat mendukung kegiatan pembelajaran anak, pelatihan militer, arsitektur, terapi, traveling dan lainnya. Keberadaan VR ini mungkin hanya dapat dijangkau oleh generasi milenial dari kalangan menengah ke atas. Karenanya diperlukan sebuah wadah yang dapat memberikan pengalaman bagi generasi milenial dan generasi apapun untuk merasakan teknologi VR ini.

\section{KAJIAN LITERATUR}

\section{Sejarah Perkembangan E-Sport}

Pertama kali budaya E-Sport berkembang dari sebuah kompetisi game. Menariknya, kompetisi game ini bahkan sudah ada sejak lama, tepatnya pada tahun 1972, pada masa yang mungkin ketika itu komputer masih amat jarang, tak ada internet, dan belum ada banyak judul video game. Ketika itu kompetisi game diadakan pada 19 Oktober 1972, diadakan di Universitas Stanford ketika itu para murid diundang ke dalam sebuah kompetisi. Setelahnya satu per satu kompetisi game lain pun bermunculan. Tahun 1980, Atari menggelar kompetisi Space Invader dengan 10.000 peserta! Terbesar di masanya. Bahkan ketika itu, kompetisi game terbilang menjadi fenomena, dan diangkat oleh majalah ternama Amerika Serikat, Life dan Time.

\section{Syarat Sebuah Games menjadi E-Sport}

Syarat-syarat yang harus dipenuhi untuk disebut sebagai E-Sport adalah:

- Gameplay yang kompetitif atau bisa dikompetisikan

- Keseimbangan dalam permainan

- Terdapat Player dan Penonton / dapat diobservasi

- Komunitas yang aktif untuk mengembangkan E-Sport

Genre-genre game yang masuk dalam E-Sports yaitu :

- MOBA (Multiplayer Online Battle Arena)

- $\quad$ FPS (First Person Shooter)

- $\quad$ Sports Game

- Racing Game

- $\quad$ Fighting Game

- $\quad$ RTS (Real Time Strategy)

- Others Game 
Ada beberapa game yang disediakan untuk lebih difokuskan sebagai E-Sport yang akan ditandingkan baik secara nasional maupun internasional yaitu :

Tabel 1. Spesifikasi dari sebuah Games

\begin{tabular}{|c|c|c|c|}
\hline Nama Permainan & Genre & $\begin{array}{l}\text { Total Turnamen yang } \\
\text { telah diselenggarakan }\end{array}$ & Jumlah Pemain \\
\hline Dota 2 & MOBA & 1061 & $752.961-927.664$ players \\
\hline $\begin{array}{l}\text { Counter Strike Global } \\
\text { Offensive }\end{array}$ & FPS & 3857 & $413.947-676.526$ players \\
\hline Mobile Legend & MOBA & 7 dari Developer & 20 juta dari Indonesia \\
\hline $\begin{array}{ll}\text { Player } & \text { Unknown } \\
\text { Battleground } & \\
\end{array}$ & Battle Royale & 115 & $\begin{array}{lll}800.719 & - & 1.026 .549 \\
\text { players } & & \\
\end{array}$ \\
\hline League of Legends & MOBA & 2208 & 27 juta players/hari \\
\hline
\end{tabular}

Sumber: Dokumentasi Pribadi, 2019

\section{Target User E-Sport dan Dampak dari E-Sport}

Target dari permainan E-Sport ini adalah orang-orang muda - dewasa, yang menekuni $E$ Sport dengan serius. Generasi milenial salah satunya yang sangat tinggi untuk menjadi target dari E-Sport. Karena perkembangan game terbesar terjadi pada zaman generasi milenial serta perkembangan teknologi sangat pesat terjadi setelah tahun 2000-an.

Tabel 2. Demografi Pelaku

\begin{tabular}{l} 
Mobile Gamer Share in Select Countries in Southeast \\
Asia, by Demographic, 2016 \\
\% of respondents \\
\hline \\
\hline
\end{tabular}

Note: numbers may not add up to $100 \%$ due to rounding

Source: Newzoo, "The GMGC Mobile Games Whitebook," Jan 12, 2017

\section{Program Bangunan untuk E-Sport yang disediakan dari dulu}

Perkembangan game pertama yaitu konsol game yang membutuhkan ruang tetap untuk bermain karena membutuhkan sebuah layar output untuk bermain dan pada umumnya adalah televisi. Kemudian berkembang menjadi game komputer sederhana. Keberadaan komputer ini membutuhkan supply listrik dari luar sehingga dibutuhkan sebuah ruang yang dapat memberikan supply listrik itu dan dengan adanya internet menjadikan game semakin berkembang dan dapat dimainkan secara online bersama-sama. Ketika game semakin berkembang dan dapat dimainkan secara online, keberadaan Warnet (Warung Internet) pun menjadi sangat dibutuhkan. Akan tetapi program ruang pada warnet yang banyak dijumpai adalah memperkecil ruang gerak dan memperbanyak keberadaan komputer-komputer. Bahkan keberadaan AC menjadi sangat penting karena banyaknya pengunjung dalam warnet menyebabkan suhu ruangan naik belum termasuk suhu dari komputer itu sendiri. 
Pada tahun 2012-an keberadaan warnet pun mulai berkurang dikarenakan internet dan komputer sudah mulai dapat dijangkau oleh siapapun. Akan tetapi developer-developer game mulai memasuki pasar mobile. Hasilnya adalah banyak game-game genre MOBA / yang dapat dimainkan bersama secara online mulai menjadi peringkat pertama. Kebutuhan ruang untuk game-game mobile ini tidak terlalu luas untuk kalangan sendiri akan tetapi ketika terdapat sebuah komunitas / kelompok bermain maka diperlukan sebuah program yang dapat menampung mereka.

Tipologi untuk program E-Sports sendiri belum ada tetapi yang pasti adalah harus memiliki kesan FUTURISTIK karena mengikuti perkembangan teknologi yang terus maju. Bahkan dapat menunjang keberadaan teknologi VR yang muncul pada generasi $Z$.

\section{Hasil Survey tentang E-Sport}

Keberadaan dan perkembangan E-Sports ini pun telah disurvey oleh sebuah badan atau perusahaan bernama Foley. Foley adalah sebuah perusahaan untuk mendekati layanan klien dengan terlebih memahami prioritas, tujuan, dan tantangan kliennya. Jadi Foley seperti sebuah analisator untuk sebuah tantangan. Mereka juga menganalisis industry E-Sport yang akan dihadapi kedepannya. Cara - cara mereka menganalisis pertama dengan membagikan survey secara online. Kantor mereka terdapat di Amerika ,Meksiko, Eropa dan Asia. Mereka juga berpendapat bahwa user atau pemain E-Sports ini berada diantara umur 18-35 tahun. Survey ini dilakukan pada tahun 2017 yang berarti bahwa umur 18-35 tahun adalah generasi milenial yang lahir antara tahun 1992 - 1999. Mereka juga memberikan survey tentang apa yang paling mendorong $E$-Sports itu sendiri bahkan terdapat sebuah survey mengenai perlunya sebuah fasilitas yang membantu para atlet E-Sports untuk lebih berkembang. Alasan kenapa Foley menjadi salah satu sumber data dari analisis E-Sport di Indonesia karena Indonesia tertinggal dari negara-negara yang sudah maju. Seperti contohnya Amerika, keberadaan pertandingan E-Sport telah diperkirakan sejak sebuah games itu muncul. Karena itu industry ESports di Amerika telah sangat maju. Bahkan di Singapore dan Malaysia, Industri E-Sport negara itu pun sudah berkembang terutama di Singapore. Banyak event-event E-Sport Internasional diadakan di negara itu. Sedangkan di Indonesia sendiri baru mulai diadakan dari Sea Games 2018 kemaren. Jadi Indonesia sendiri juga mulai mentargetkan untuk mengikuti beberapa pertandingan E-Sport di dunia Internasional. Inilah hasil survey dari Foley terhadap perkembangan dan kebutuhan yang diperlukan untuk E-Sports :

1 RANK THE FOLLOWING FROM 1 BEING THE AREA YOU EXPECT TO DRIVE THE MOST REVENUE GROWTH IN THE ESPORTS INDUSTRY OVER THE NEXT YEAR TO 5 BEING THE LEAST.

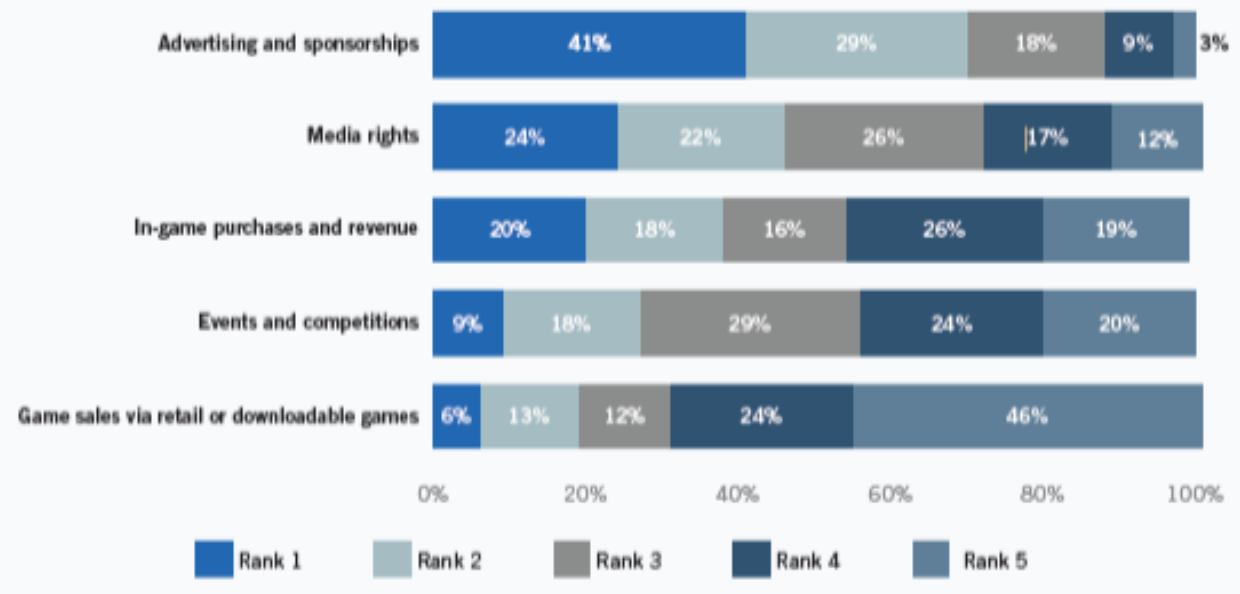

Gambar 1. Survey tentang apa yang sangat berdampak dalam pertumbuhan E-Sports. Sumber: Penulis, 2019 
2 HOW MUCH IMPACT DO YOU FEEL THE FOLLOWING DEVELOPMENTS HAVE HAD ON DRIVING THE GROWTH OF THE ESPORTS INDUSTRY OVER THE LAST YEAR?
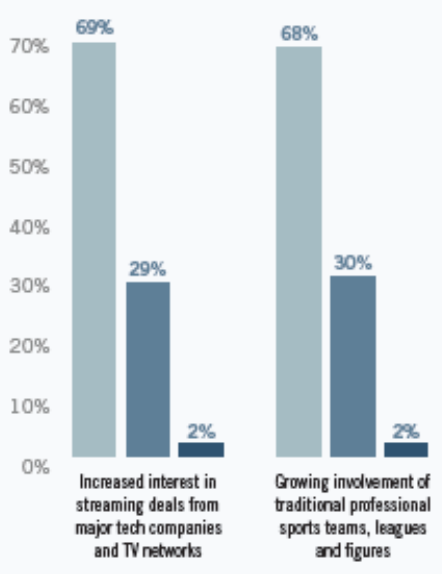
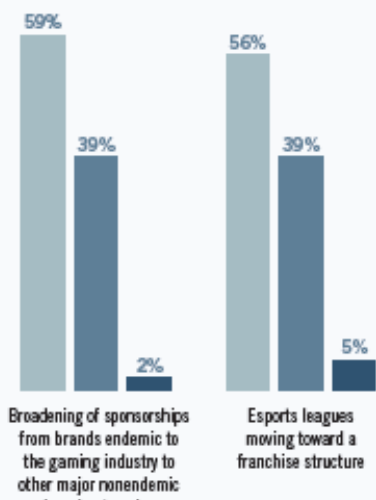

Esparts leagues mowing toward a franchise strusture trand categonies

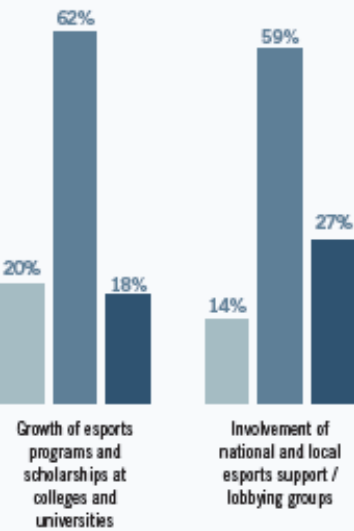

Gambar 2. Dampak yang paling terasa dari kemajuan Industri E-Sports Sumber: Penulis, 2019

FOR EACH OF THE FOLLOWING ITEMS, PLEASE INDICATE THE LEVEL OF RISK YOU THINK IT POSES TO THE LEGITIMACY AND GROWTH OF THE ESPORTS INDUSTRY.

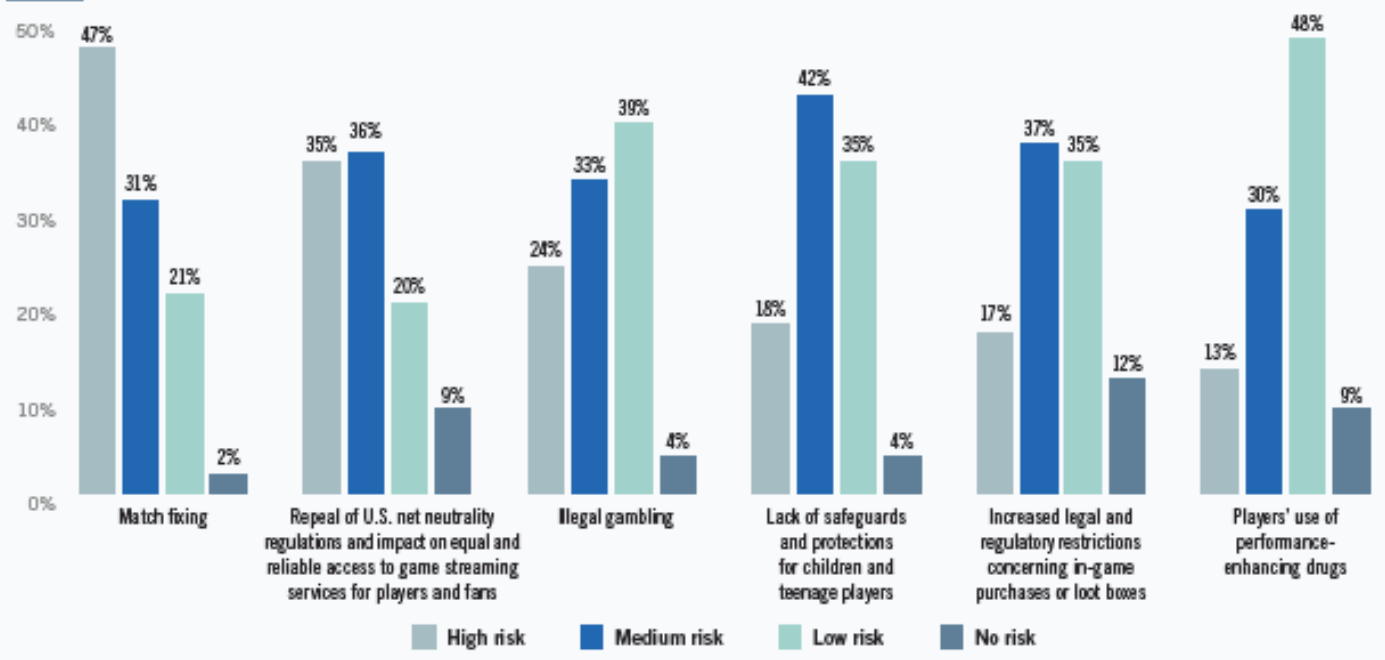

Gambar 3. Resiko yang akan muncul dari pertumbuhan E-Sport Sumber: Penulis, 2019 
6 WHICH OF THE FOLLOWING DO YOU EXPECT TO BE A FOCUS IN THE DEBATE OVER GAMBLING IN ESPORTS OVER THE NEXT YEAR? (CHECK ALL THAT APPLY)

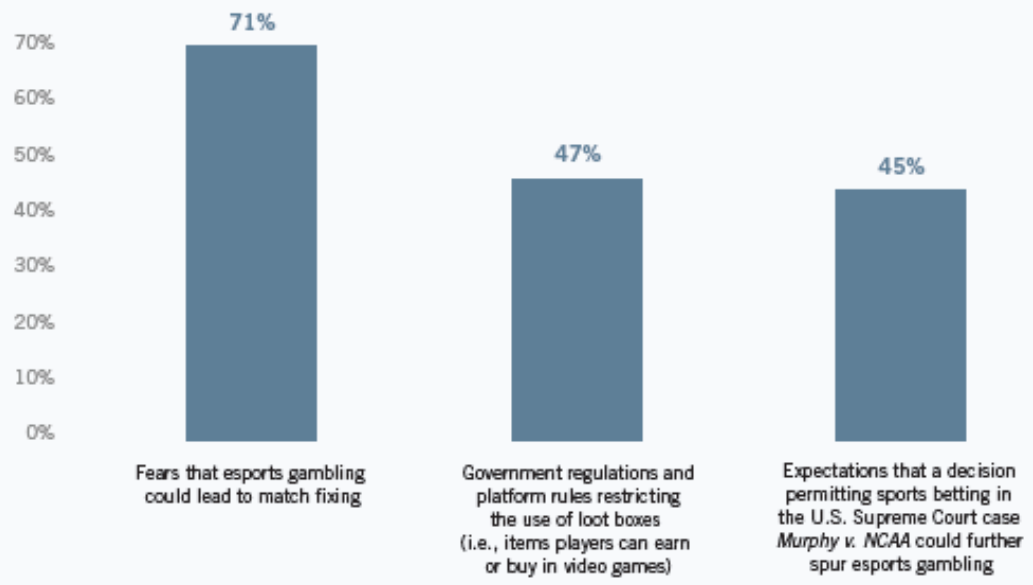

Gambar 4. Yang harus difokuskan untuk diperdebatkan tentang judi dalam E-Sport Sumber: Penulis, 2019

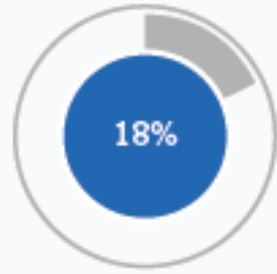

Strongly agree

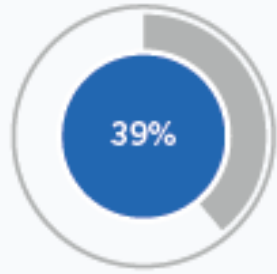

Agree

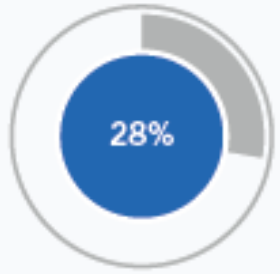

Neutral

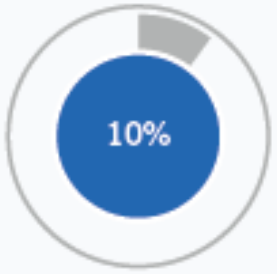

Disagree

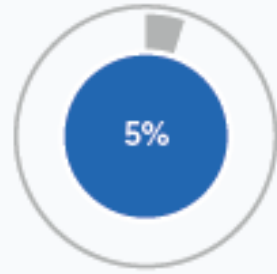

Strongly disagree

Gambar 5. Perlunya fasilitas untuk mengkoordinasi event dalam E-Sports Sumber: Penulis, 2019 ESPORTS PLAYERS.

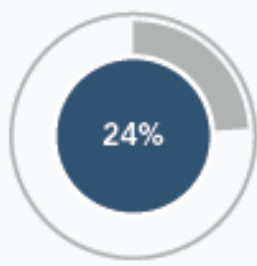

Strongly agree

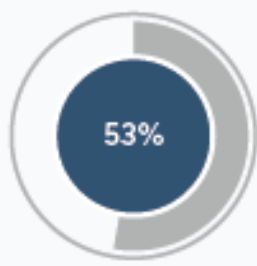

Agree

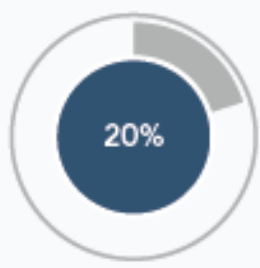

Neutral

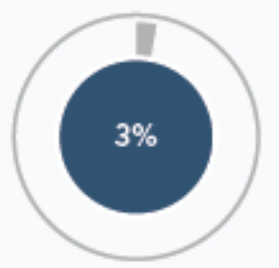

Disagree

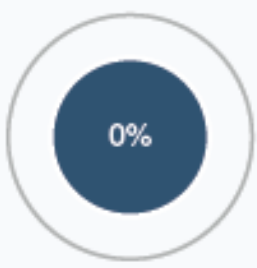

Strongly disagree

Gambar 6. Perlunya asosiasi untuk memfokuskan minat atlet $E$-Sports profesional Sumber: Penulis, 2019 
TO WHAT EXTENT DO YOU AGREE WITH THE FOLLOWING STATEMENT: ESPORTS NEEDS A SINGLE, OVERARCHING GOVERNING BODY TO REGULATE THE INDUSTRY AND SET UNIFORM RULES.

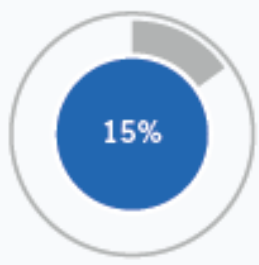

Strongly agree

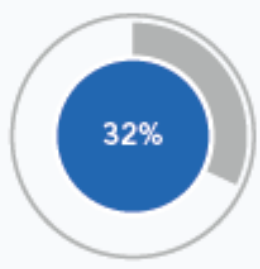

Agree

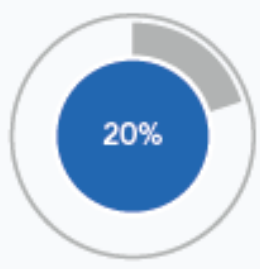

Neutral

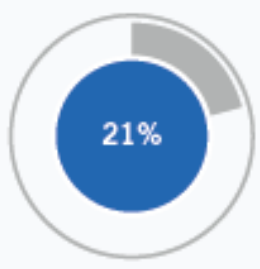

Disagree

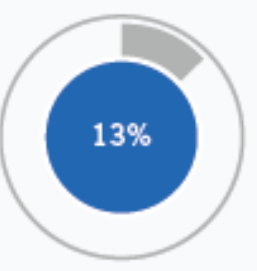

Strongly disagree

Gambar 7. E-Sports membutuhkan regulasi dari pihak pemerintah Sumber: Penulis, 2019

\section{METODE DESAIN}

Metode desain menggunakan Metode Preseden, dikarenakan program E-Sport belum memiliki tipologi bangunannya. Metode preseden dilakukan dengan 2 cara yaitu :

a. Survey Lapangan yang berhubungan dengan program E-Sport seperti warnet / E-Sport arena yang ada, Contoh : Mineski Infinity Arena

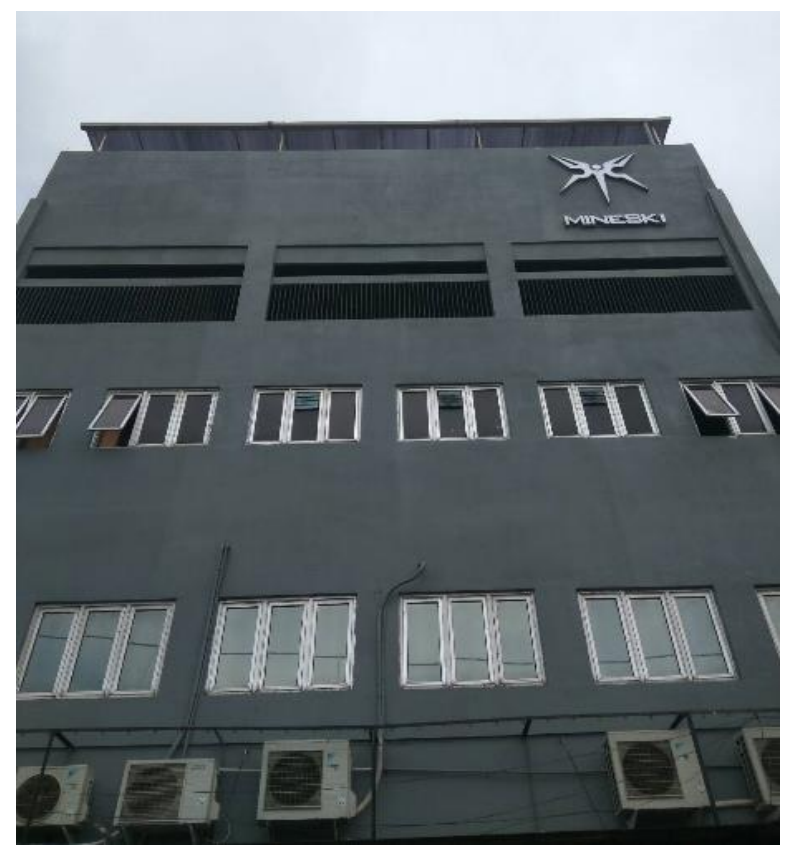

Gambar 8. Facade Bangunan

Sumber: Penulis, 2019

Lokasi : Jl. Tanjung Duren Barat, Jakarta Barat

Bentuk Bangunan : 3 Ruko menjadi 1

Bentukan Dasar : persegi panjang 


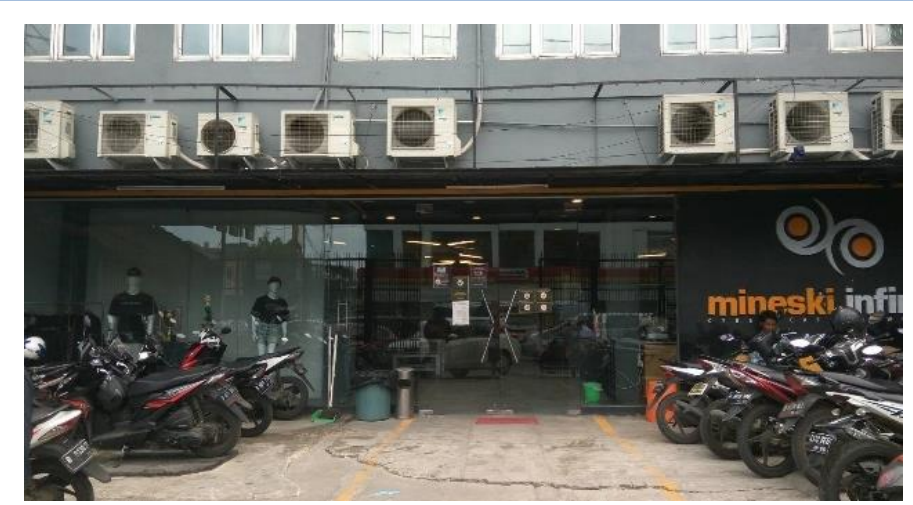

Gambar 9. Pintu Masuk dan Parkiran

Sumber: Penulis, 2019

Program ruang di dalamnya :

- Lahan Parkir Motor

- Lobby dan Waiting Area

- E-Sport Area VVIP

- E-Sport Area VIP

- Cashier \& Cafetaria

- Toilet

- E-Sport Practice Area.

- Aktivitas yang terjadi : ada mobile E-Sport area, latihan E-Sport, bermain E-Sport.

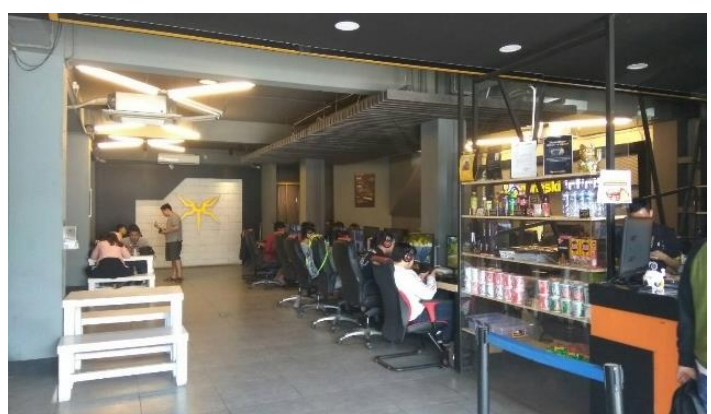

Gambar 10. Lobby Area dan E-Sport Area Sumber: Penulis, 2019

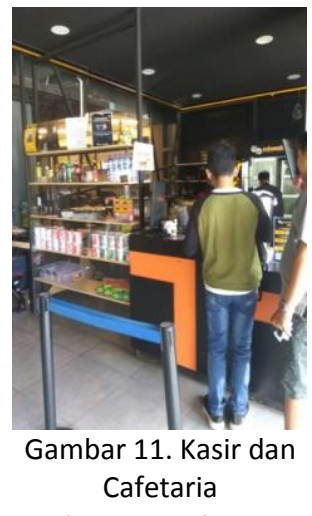

Sumber: Penulis, 2019

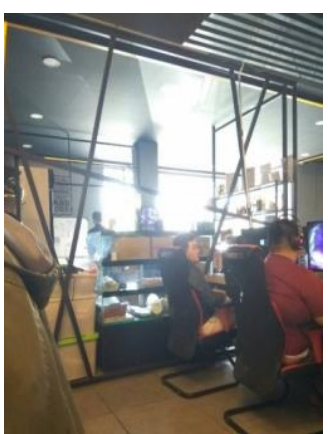

Gambar 12. Hubungan Ruang antara E-Sport area dan Kasir

Sumber: Penulis, 2019

- Facade : Facade bangunan berwarna abu-abu gelap, abu-abu merupakan warna yang dianggap memberi kesan future,

- Sistem Struktur : sistem struktur kolom beton bentuk persegi dan baloknya diexpose.

- Penggunaan Material : penggunaan material bata, dan kaca pada interiornya terdapat aluminium dan polycarbonet.

- Orientasi dan Penghawaan : bangunan menghadap ke arah selatan dan terdapat area parkir untuk massa. Penghawaannya terdapat AC Split dan AC Sentral

- Pencahayaan : Sistem pencahayaan menggunakan lampu Neon yang ditata membentuk huruf $X$

- Vegetasi : tidak ada sistem penyerapan ataupun vegetasi

- Kapasitas : 114 komputer untuk pengunjung 


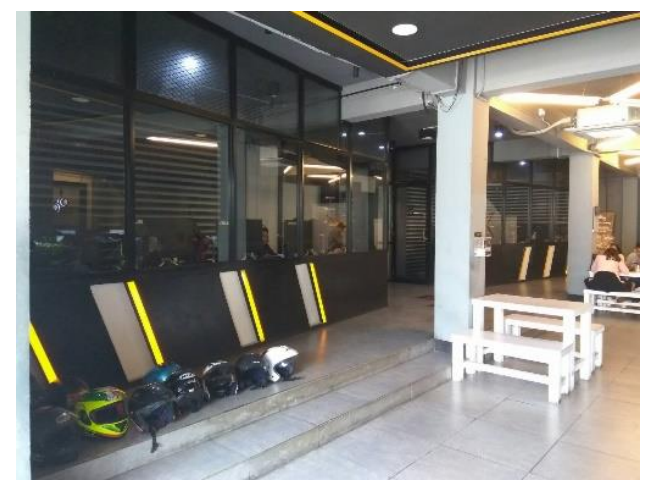

Gambar 13. VVIP / Pelatihan Arena Sumber: Penulis, 2019

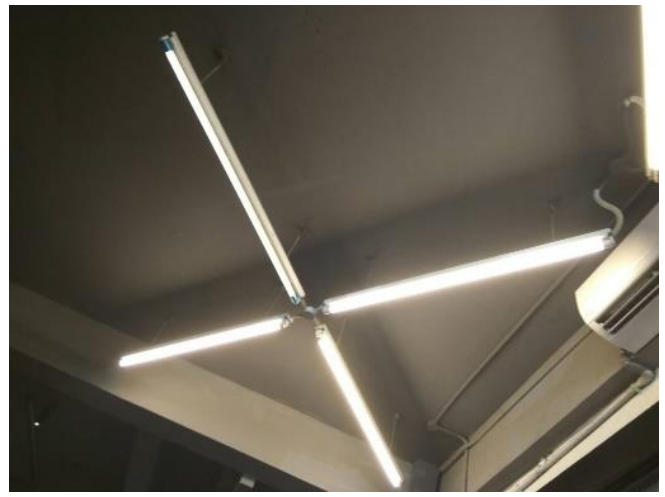

Gambar 14. Pencahayaan Neon Sumber: Penulis, 2019

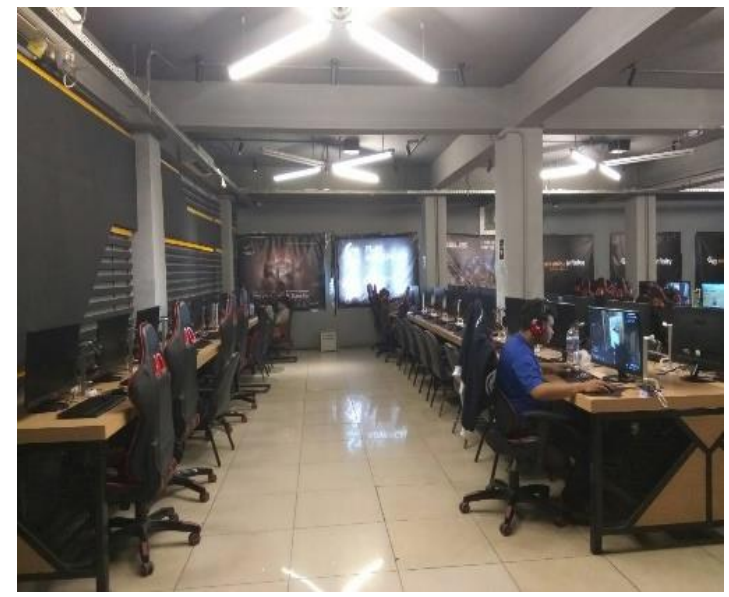

Gambar 15. E- Sport Area

Sumber: Penulis, 2019

b. Studi Literatur : Studi terhadap bentuk, program ruang, material bangunan serta aktivitas yang tercantum dalam sumber. Contoh Indonesia E-Sport Stadium Lokasi : Jalan Pluit Selatan No 6 Jakarta Utara Bentuk Ruang yang terlampir dari foto adalah sebuah ruang bentang lebar berbentuk persegi. Fungsi bangunan utama sebagai sarana tempat berlangsungnya Pertandingan E-Sport. Yang kedua sebagai area pelatihan E-Sport. 


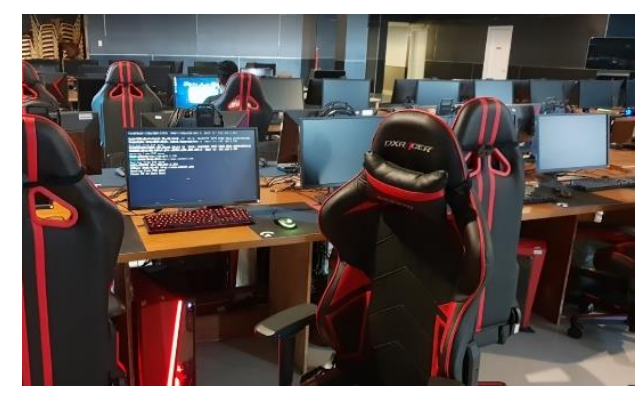

Gambar 16. Area Pelatihan Sumber: Penulis, 2019

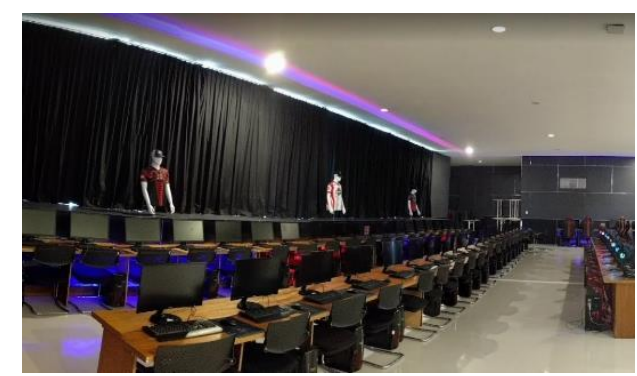

Gambar 17. Area Bermain E-Sport Sumber: Penulis, 2019

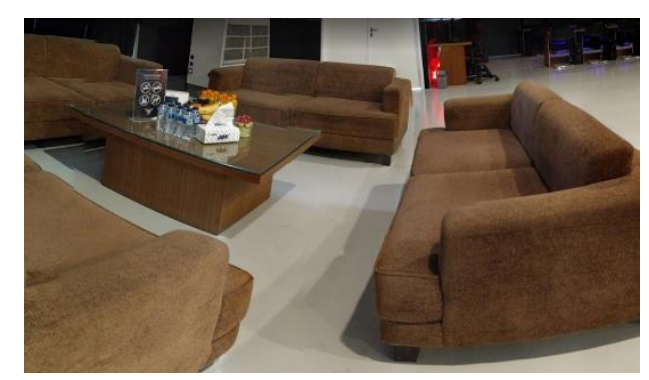

Gambar 18. Lounge

Sumber: Penulis, 2019

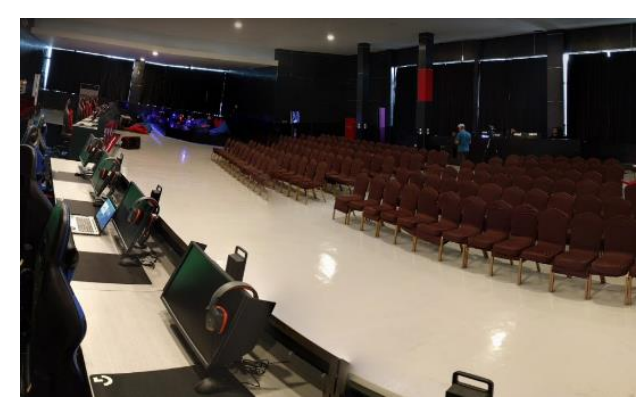

Gambar 19. Stadium

Sumber: Penulis, 2019

\section{DISKUSI DAN HASIL}

Hasil dari Survey lapangan lebih diutamakan dalam proses design. Terdapat 3 destinasi yang memiliki program yang sama dengan program yang akan di desain. 
Program ruang dan aktivitas yang terjadi dalam bangunan dapat dilihat dari tabel dan skema berikut:

\begin{tabular}{|c|c|c|c|c|c|c|c|c|c|}
\hline Ruang & sifat ruang & Kapasitas & Ruang & dimensi /orang atau / rua & Luas & Luas & Sirkulasi & Luas Total & Posisi \\
\hline \multirow{3}{*}{ PC Area } & Reguler & 60 & 1 & $80 \mathrm{~cm} \times 120 \mathrm{~cm}$ & 0,96 & 57,6 & 17,28 & 74,88 & \\
\hline & VIP & 40 & 1 & $100 \mathrm{~cm} \times 120 \mathrm{~cm}$ & 1,2 & 48 & 14,4 & 62,4 & \\
\hline & Platinum & 20 & 1 & $100 \mathrm{~cm} \times 120 \mathrm{~cm}$ & 1,2 & 24 & 7,2 & 31,2 & \\
\hline PC Practice Area & & 6 & 2 & $100 \mathrm{~cm} \times 120 \mathrm{~cm}$ & 1,2 & 7,2 & 2,16 & 9,36 & \\
\hline Cashier & & 4 & 1 & $80 \mathrm{~cm} \times 100 \mathrm{~cm}$ & 0,8 & 3,2 & 0,96 & 4,16 & \\
\hline Mobile Room & & 5 & 6 & $100 \mathrm{~cm} \times 60 \mathrm{~cm}$ & 0,6 & 3 & 0,75 & 3,75 & \\
\hline Mobile Practice Area & & 6 & 2 & $100 \mathrm{~cm} \times 60 \mathrm{~cm}$ & 0,6 & 3,6 & 0,9 & 4,5 & \\
\hline VR room & & 6 & 4 & $300 \mathrm{~cm} \times 300 \mathrm{~cm}$ & 9 & 9 & 2,25 & 11,25 & \\
\hline VR Shooting & & 4 & 2 & $300 \mathrm{~cm} \times 300 \mathrm{~cm}$ & 9 & 9 & 2,25 & 11,25 & \\
\hline VR Music & & 5 & 1 & $200 \mathrm{~cm} \times 200 \mathrm{~cm}$ & 4 & 4 & 1 & 5 & \\
\hline VR 9D & & 10 & 1 & $600 \mathrm{~cm} \times 600 \mathrm{~cm}$ & 36 & 36 & 9 & 45 & \\
\hline Locker room & & 40 & 1 & $240 \mathrm{~cm} \times 500 \mathrm{~cm}$ & 12 & 12 & 3 & 15 & \\
\hline Gudang & & 10 & 1 & $600 \mathrm{~cm} \times 600 \mathrm{~cm}$ & 36 & 36 & 9 & 45 & \\
\hline Security & & 16 & 1 & $400 \mathrm{~cm} \times 300 \mathrm{~cm}$ & 12 & 12 & 3 & 15 & \\
\hline P3k & & 5 & 1 & $400 \mathrm{~cm} \times 400 \mathrm{~cm}$ & 16 & 16 & 4 & 20 & \\
\hline \multirow[t]{5}{*}{ Stadium } & Penonton & 2000 & 1 & $50 \mathrm{~cm} \times 80 \mathrm{~cm}$ & 0,4 & 800 & 320 & 1120 & \\
\hline & Security & 40 & 1 & $20 \mathrm{~cm} \times 40 \mathrm{~cm}$ & 0,08 & 3,2 & 0,8 & 4 & \\
\hline & Pemain & 10 & 1 & $100 \mathrm{~cm} \times 120 \mathrm{~cm}$ & 1,2 & 12 & 3 & 15 & \\
\hline & Komentator & 4 & 1 & $100 \mathrm{~cm} \times 100 \mathrm{~cm}$ & 1 & 4 & 1 & 5 & \\
\hline & Teknisi & 20 & 1 & $100 \mathrm{~cm} \times 100 \mathrm{~cm}$ & 1 & 20 & 5 & 25 & \\
\hline Waiting Area & & 20 & 1 & $50 \mathrm{~cm} \times 60 \mathrm{~cm}$ & 0,3 & 6 & 1,5 & 7,5 & \\
\hline Komersil Area & & 4 & 10 & $300 \mathrm{~cm} \times 200 \mathrm{~cm}$ & 6 & 24 & 6 & 30 & \\
\hline Kafetaria & & 30 & 1 & $399 \mathrm{~cm} \times 500 \mathrm{~cm}$ & 19 & 19 & 4,75 & 23,75 & \\
\hline Service & & 30 & 1 & $400 \mathrm{~cm} \times 500 \mathrm{~cm}$ & 20 & 20 & 5 & 25 & \\
\hline Total Luas Bangunan & 1613 & & & & & & & & \\
\hline
\end{tabular}

Service Building 161,3

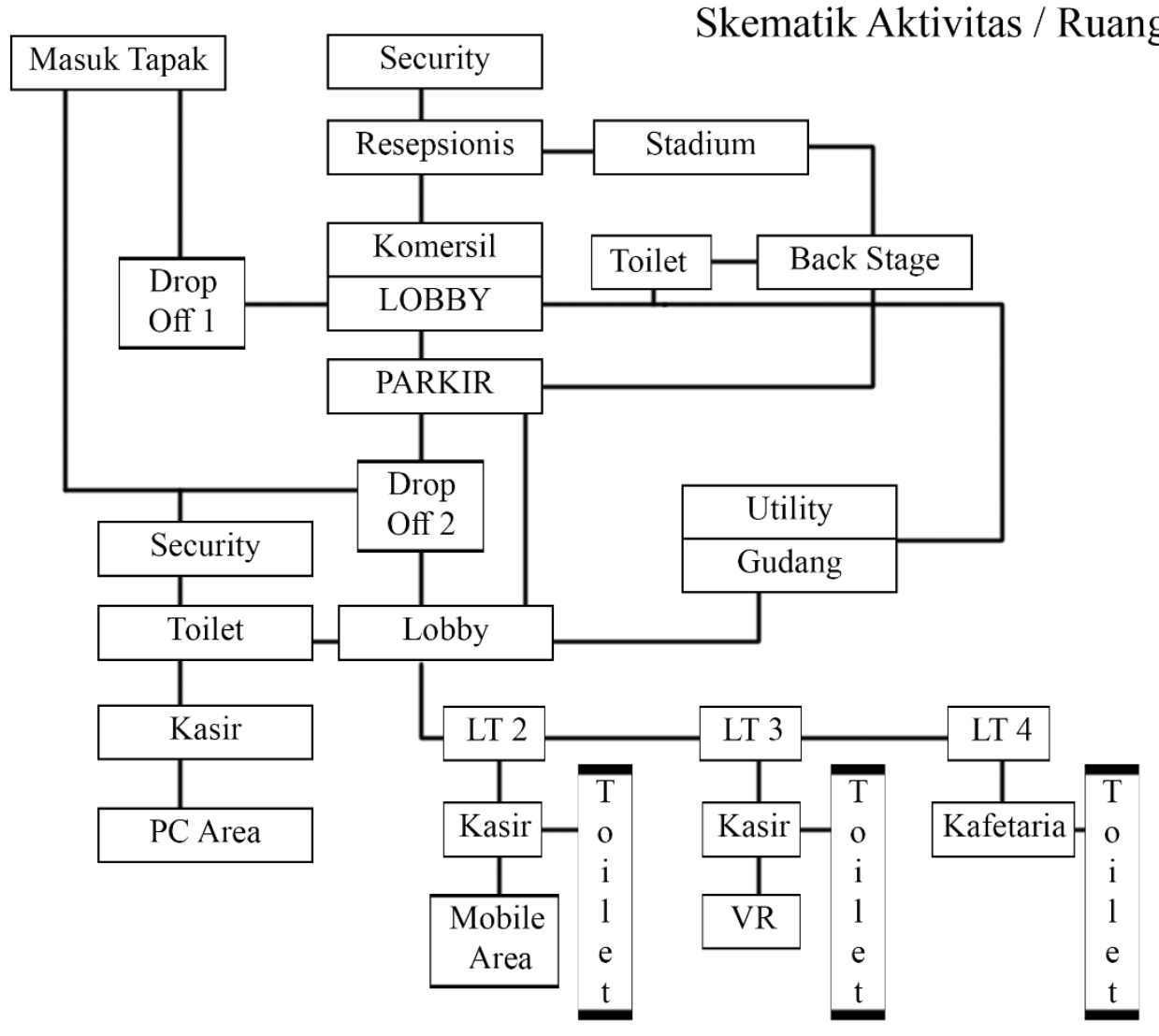

Gambar 20. Tabel Program Ruang dan Skema Aktivitas

Sumber: Penulis, 2019 
Dari hasil survey ini akan dijadikan acuan dalam mendesain program E-Sport. E-Sport berkaitan erat dengan teknologi maka dari itu konsep pada program E-Sport yang akan dirancang adalah konsep futuristik. Futuristik selain dari bahan material dan pencahayaan, bentuk yang sederhana tapi efisien untuk ruang termasuk bagian dari Futuristik. Karena pada ke depannya populasi manusia akan meningkat,maka ide untuk ruang yang efisien termasuk dalam konsep Futuristik. Penulisan dapat dibagi dalam beberapa sub bagian yang diberi judul sendiri oleh penulis berdasarkan kepentingan penjelasan dengan membubuhkan nomor urut seperti pada contoh di bagian Pendahuluan.
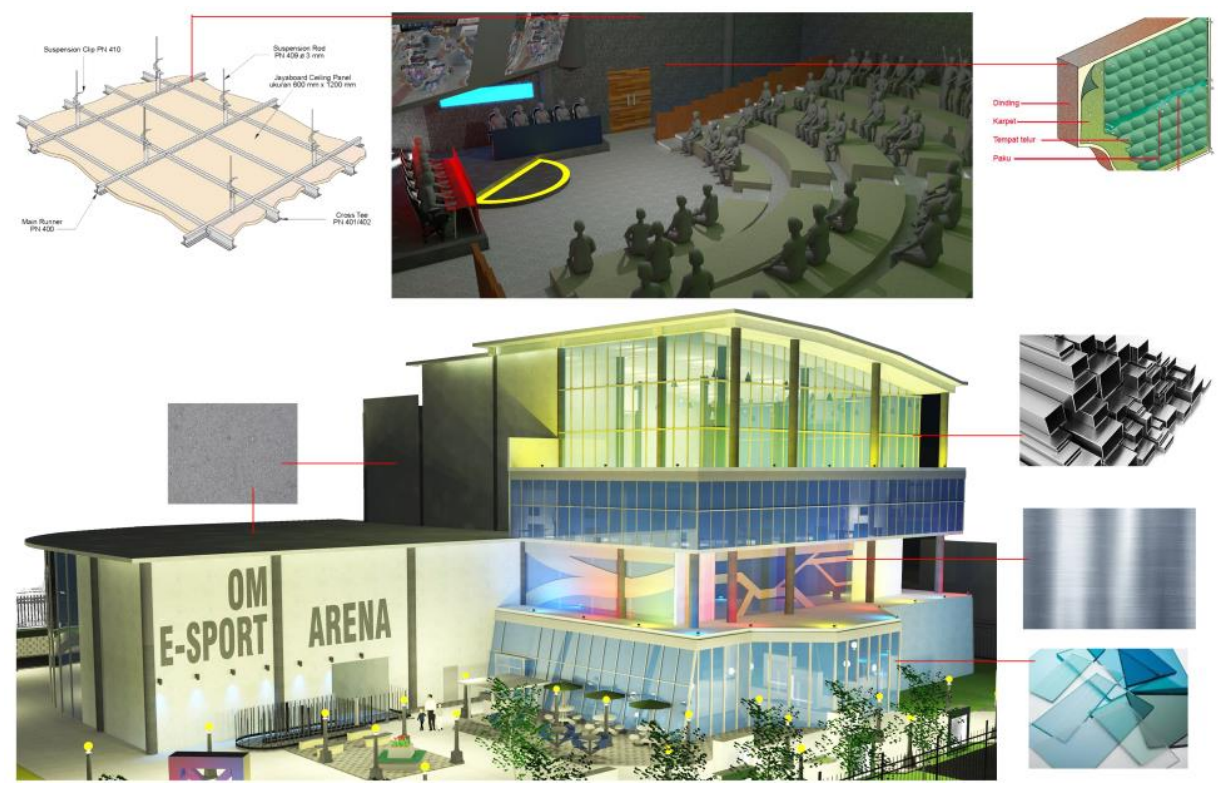

Gambar 21. Penggunaan Material Pada Desain Sumber: Penulis, 2019

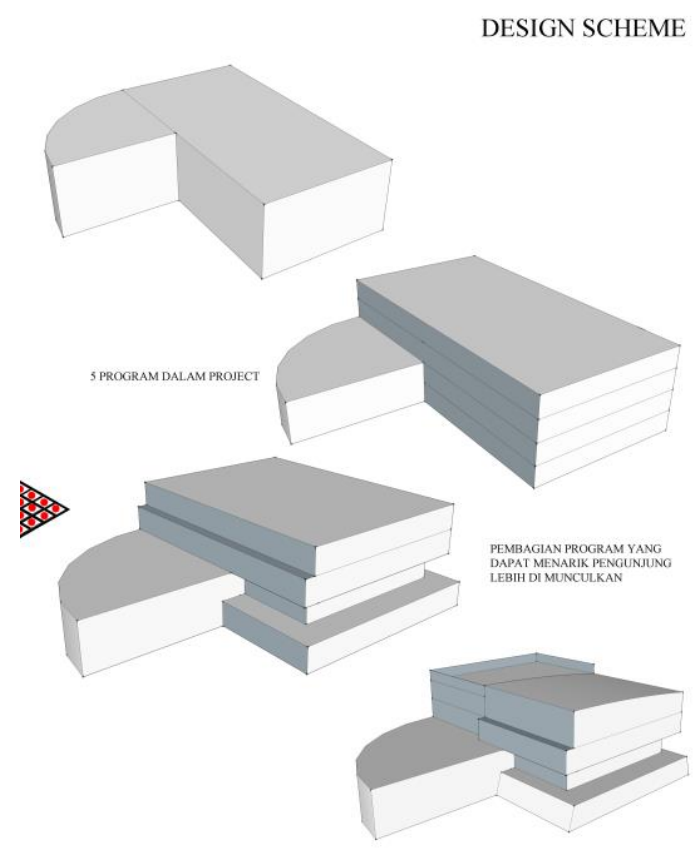

Gambar 22. Gubahan Massa

Sumber: Penulis, 2019 
Salah satu program dalam proyek adalah E-Sport Stadium yang memberikan dampak paling besar dalam proyek. Keberadaan stadium ini untuk menunjang fasilitas pelaksanaan kompetisi, seperti kita tahu di Indonesia masih sedikit fasilitas untuk berkompetisi E-Sport.

Seperti pada gambar, beberapa material yang digunakan yaitu beton, aluminium , metal cladding dan dan kaca tempered glass. Beberapa material yang disebutkan merupakan material yang menunjang konsep futuristik. Dan juga pada proses design, penentuan gubahan massa berasal dari analisis tapak yang dapat menarik lebih banyak pengunjung.
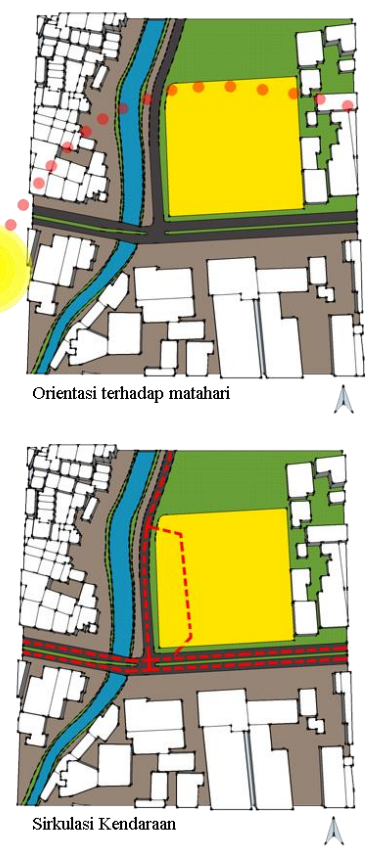
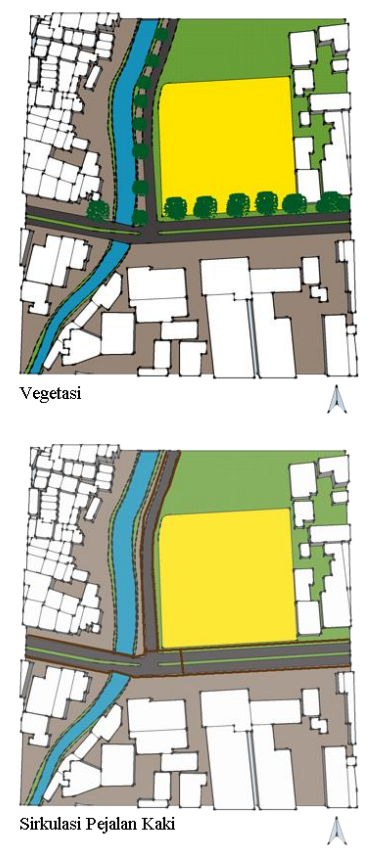
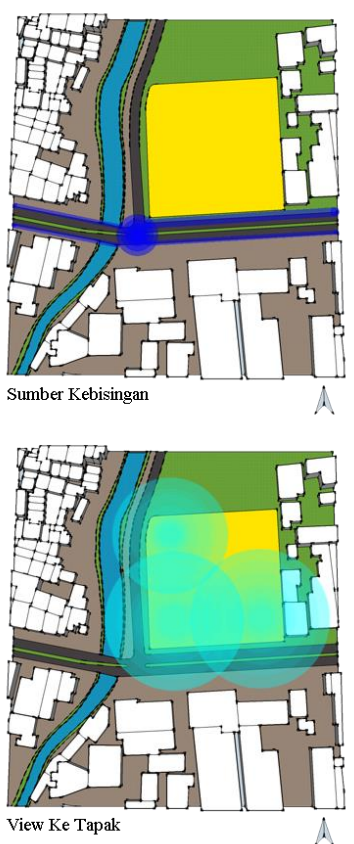

Gambar 23. Analisis Tapak

Sumber: Penulis, 2019

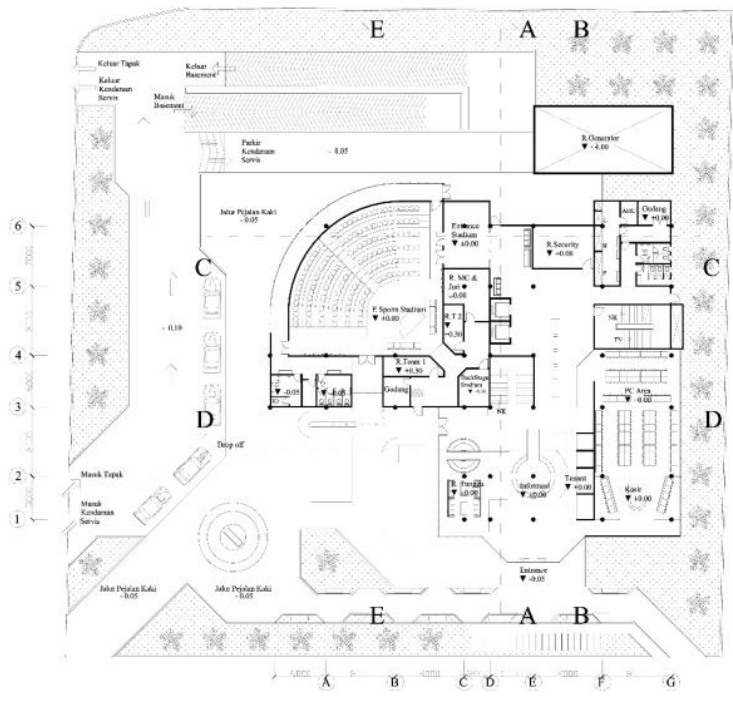

Gambar 24. Denah Lantai Dasar

Sumber: Penulis, 2019 

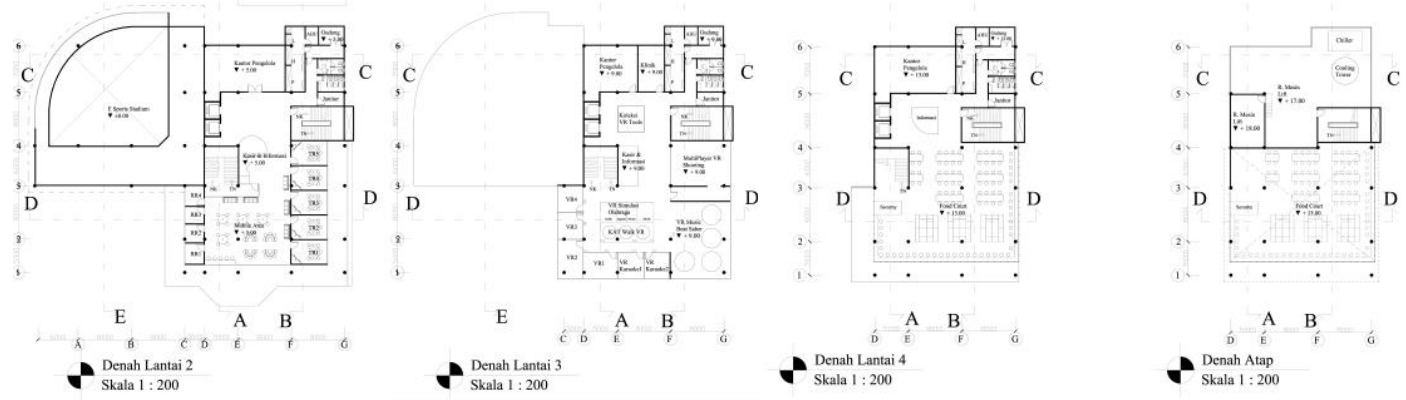

Gambar 25. Denah Lantai 2,3,4 dan Atap Sumber: Penulis, 2019

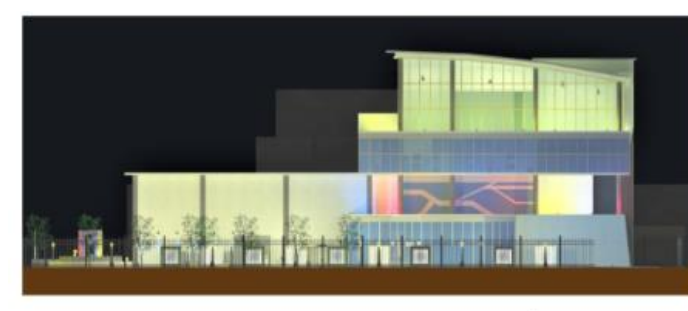

- Thala 1: 200

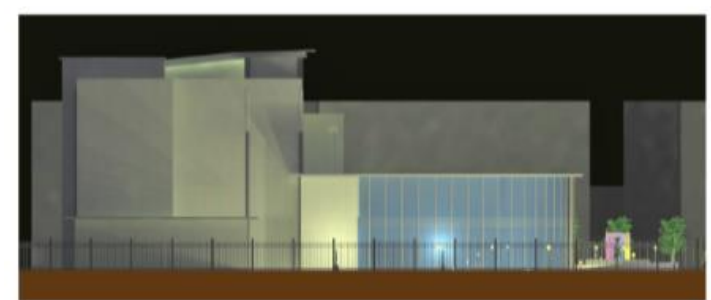

Tampak Belikang

Gambar 26. Tampak Hasil Desain

Sumber: Penulis, 2019
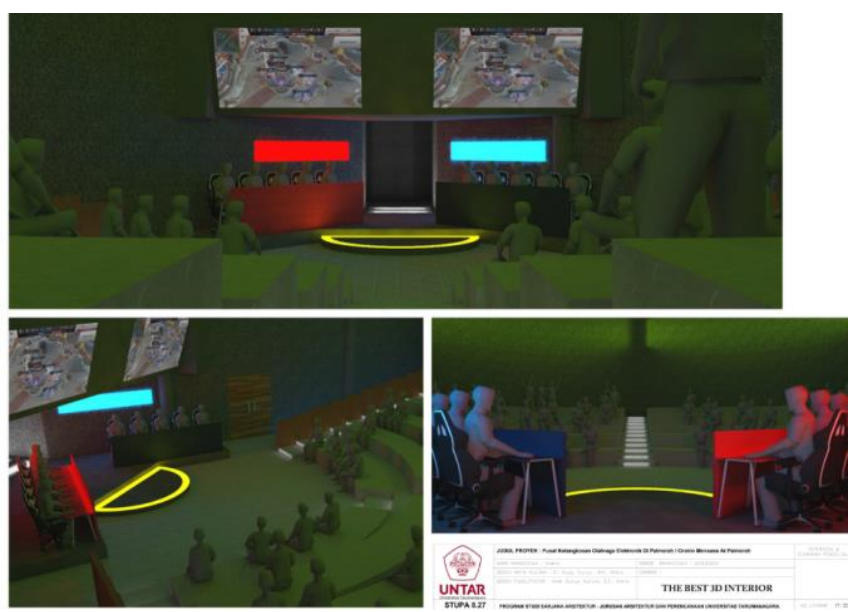

Gambar 27. 3D Interior Stadium

Sumber: Penulis, 2019 


\section{KESIMPULAN DAN SARAN}

\section{Kesimpulan}

Kebutuhan E-Sport arena sangat diperlukan, dengan adanya E-Sport arena ini diharapkan dapat menunjang kemampuan Atlet dan menambah minat masyarakat terhadap cabang olahraga ini. Karena di Indonesia memiliki banyak masyarakat yang bertalenta dalam E-Sport hanya saja tidak diasah dengan baik. Selain itu keberadaan E-Sport arena ini diharapkan dapat menjadikan Indonesia sebagai salah satu tuan rumah E-Sport internasional dan menarik wisatawan dari luar mengingat bahwa peminat $E$-Sport di dunia cukup banyak.

\section{Saran}

Akan lebih baik ketika dapat melakukan survey lapangan di luar Indonesia, karena tipologi E-Sport di setiap negara berbeda terutama di negara yang berkembang dalam E-Sport. Jika dimungkinkan, desain E-Sport lebih dapat dimaximalkan dengan penambahan Sekolah khusus E-Sport dan Asrama, sehingga dapat menjadi sebuah program yang menghasilkan lebih banyak atlet yang dilatih.

\section{REFERENSI}

Baldwin, E. (2019). Populous Designs the Western Hemisphere's Largest Esports Arena, diunduh 26 Maret 2019, <https://www.archdaily.com/913921/populous-designs-thewestern-hemispheres-largest-esports-arena>, Archdaily.

Braza, M. K. dkk. (2018). 2018 Esports Survey Report, diunduh 24 Juli 2018, $<$ https://www.foley.com/en/insights/publications/2018/07/2018-esports-surveyreport>, Foley and lardner Ilp.

Harari, Y. N. (2015). Homo Deus masa depan umat manusia. Jakarta : Pustaka Alvabet.

Honggowidjaja, E. J., dkk (2016). Perancangan Interior Fasilitas E-Sports Arena. JURNAL INTRA Vol. 4, No. 2, (2016) 672-681.

Overstreet, K. (2018), Populous to Collaborate on Design of North America's First eSports Stadium, diunduh 29 Maret 2018, <https://www.archdaily.com/891105/populous-tocollaborate-on-design-of-north-americas-first-esports-stadium $>$, Archdaily.

Vincent, B. (2018). Riot Games Opens New 'League of Legends' Esports Stadium in South Korea, diunduh 3 Oktober 2018, <https://variety.com/2018/gaming/news/league-of-legendsesports-stadium-1202967094/>, Variety.

Wiguna, M. A. dan Ardiyan S. W. (2016). Bandung eSport Arena Membangun Ekosistem eSport di Indonesia. JURNAL SAINS DAN SENI ITS Vol. 5, No.2,(2016) 2337-3520 (2301928XPrint). 
